\title{
Helicobacter pylori infection potentiates the inhibition of gastric acid secretion by omeprazole
}

\author{
D Gillen, A A Wirz, W D Neithercut, J E S Ardill, K E L McColl
}

\begin{abstract}
Background-Omeprazole has a greater intragastric pH elevating effect in Helicobacter pylori positive than negative subjects. Ammonia production by $H$ pylori has been suggested as a probable mechanism.

Aims-To assess the effect of $\boldsymbol{H}$ pylori status on gastric acid secretion during omeprazole treatment, and to examine the possible role of ammonia neutralisation of intragastric acid in increased omeprazole efficacy in infected subjects.

Methods-Twenty $\mathrm{H}$ pylori positive and 12 $H$ pylori negative healthy volunteers were examined before and six to eight weeks after commencing omeprazole $40 \mathrm{mg} /$ day. On both occasions plasma gastrin and acid output were measured basally and in response to increasing doses of gastrin 17 (G-17). Gastric juice ammonium concentrations were also measured.

Results-Prior to omeprazole, measurements were similar in the $H$ pylori positive and negative subjects. During omeprazole, median basal intragastric $\mathrm{pH}$ was higher in the $H$ pylori positive (7.95) versus negative $(3.75)$ subjects $(p<0.002)$. During omeprazole basal, submaximal (180 pmol/kg/h G-17), and maximal acid outputs (800 pmol/kg/h G-17) were lower in $H$ pylori positive subjects $(0.0,3.6,6.0$ $\mathrm{mmol} / \mathrm{h}$ respectively) versus negative subjects $(0.3,14.2,18.6 \mathrm{mmol} / \mathrm{h}) \quad(p<0.03$ for each). This effect was not explained by neutralisation by ammonia.
\end{abstract}

University

Department of

Medicine and

Therapeutics,

Western Infirmary,

Glasgow G11 6NT, UK

D Gillen

A A Wirz

KE L McColl

Arrowe Park Hospital, Upton, Wirral,

Merseyside, UK

W D Neithercut

Department of

Medicine, The Queen's

University of Belfast,

Royal Victoria

Hospital, Belfast, UK

J E S Ardill

Correspondence to:

Professor McColl.

Accepted for publication 7 October 1998

Omeprazole, a substituted benzimidazole, noncompetitive inhibitor of the gastric proton pump, ${ }^{12}$ has become one of the world's most frequently prescribed medications. ${ }^{3}$ Early studies in duodenal ulcer patients ${ }^{4}$ and healthy volunteers ${ }^{5}$ showed its efficacy in producing profound suppression of acid secretion. This ability has been utilised with great success in a wide spectrum of acid related disorders. ${ }^{6-9}$
After the introduction of omeprazole, $H$ pylori was recognised as a highly prevalent infectious agent of the gastric mucosa in both dyspeptic patients ${ }^{10-12}$ and asymptomatic healthy individuals. ${ }^{13}{ }^{14}$ Omeprazole has been shown to exert effects on $H$ pylori ${ }^{15}{ }^{16}$ and the associated gastritis. ${ }^{17-20}$

The presence of $H$ pylori infection may also exert effects on the actions of omeprazole. Four studies have shown that intragastric $\mathrm{pH}$ during omeprazole treatment is higher in $H$ pylori infected subjects than in $H$ pylori negative or eradicated subjects. ${ }^{21-24}$ The investigators in these studies have concluded that the greater elevation of $\mathrm{pH}$ on omeprazole in the presence of $H$ pylori is mainly due to production of ammonia by its urease enzyme, ${ }^{25}$ neutralising intragastric acid.

The aims of this study were: (1) to assess the effect of $H$ pylori status on gastric acid secretion, as opposed to intragastric $\mathrm{pH}$, during proton pump inhibitor (PPI) treatment; and (2) to assess the contribution of $H$ pylori ammonia production to any effects observed. Our findings show that the presence of $H$ pylori leads to notably greater suppression of basal, submaximal, and maximal acid secretion during PPI treatment. They also show that ammonia production by $H$ pylori and, indeed, neutralisation from any other source, cannot explain these observations.

\section{Materials and methods}

SUBJECTS STUDIED

Twenty $H$ pylori negative healthy volunteers (10 men, five smokers) and $12 \mathrm{H}$ pylori positive healthy volunteers (four men, four smokers) were studied. The mean weight and age of the $H$ pylori negative volunteers were $75.9 \mathrm{~kg}$ and 27.9 years; those of the $H$ pylori positive volunteers were $71.4 \mathrm{~kg}$ and 29.5 years. None of these volunteers were taking any medication, other than oral contraceptives. None reported any major gastrointestinal symptoms.

$H$ pylori status was determined using the ${ }^{14} \mathrm{C}$-urea breath test. This test has been validated in our unit: using a cut off value of 30 ( $\mathrm{kg} \%$ dose $/ \mathrm{mmol} \mathrm{CO}_{2}$ ) for the 20 minute result it has a sensitivity of $98 \%$ and a specificity of $100 \%{ }^{26}$
METHODS

Basal gastrin concentration, basal intragastric $\mathrm{pH}$, and basal acid output were measured in all subjects. Acid output was then measured in

Abbreviations used in this paper: $\mathrm{BAO}$, basal acid output; ECL, enterochromaffin-like; G-17, gastrin 17; GORD, gastro-oesophageal reflux disease; MAO, maximal acid output; PPI, proton pump inhibitor. 


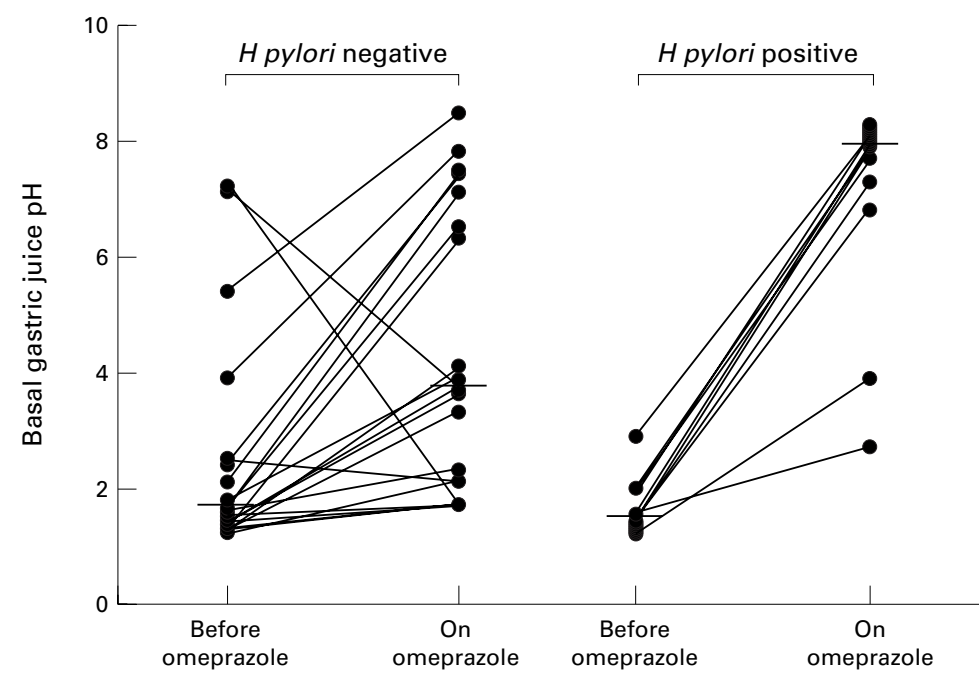

Figure 1 Basal fasting gastric juice $p H$ in $H$ pylori negative and positive subjects before and during omeprazole treatment. Medians are represented by horizontal bars.

response to submaximal and maximal doses of gastrin 17 (G-17). Following this, the subjects took an eight week course of omeprazole $40 \mathrm{mg}$ each morning (at 0900 hours) (Astra Hassle, Molndal, Sweden) with weekly reminder telephone calls and fortnightly tablet counts being carried out. During the last two weeks of this course, the gastrin and acid secretory studies were repeated 24 hours after the previous dose of omeprazole.

For the gastric secretory studies, all subjects reported at 0900 after a 12 hour fast. A $16 \mathrm{~F}$ nasogastric tube (Andersen Inc., New York, USA) was passed and its position in the dependent part of the stomach was checked using the water recovery test. ${ }^{27}$ After the stomach was emptied, intermittent suction was applied using an intermittent suction unit (Ohmeda, Columbia, Maryland, USA), which applies suction for 20 seconds in each 32 second cycle. A 30 minute basal acid collection was obtained, then sequential 30 minute collections were made during infusions of G-17 at doses of $7,20,60,180$, and $800 \mathrm{pmol} / \mathrm{kg} / \mathrm{h}$. Blood samples were collected each morning for gastrin determination, both basally and at the end of each infusion period. The plasma was stored at $-20^{\circ} \mathrm{C}$. A gastric juice sample was taken at the end of both the basal and the peak G-17 infusion periods for later ammonium measurement. These gastric juice samples were stored at $-70^{\circ} \mathrm{C}$. Basal samples at both time points were unavailable for two of the $H$ pylori negative subjects and one of the $H$ pylori positive subjects, maximal samples for six of the $H$ pylori negative subjects and three of the $H$ pylor $i$ positive subjects. The $\mathrm{pH}$ and volume of each acid collection was noted and its hydrogen ion concentration was measured by titration with $0.1 \mathrm{M}$ sodium hydroxide to $\mathrm{pH} 7.0$ using an autotitrator (Radiometer ETS 822, Copenhagen, Denmark).

G-17 was purchased from Peninsula Laboratories (Belmont, California, USA) as aliquots of freeze dried lyophilised powder. Subsequent preparation was performed under sterile conditions by the Western Infirmary Pharmacy
Department. Each aliquot was dissolved in a small volume of ammonium bicarbonate, then made up into a stock solution. Vials containing $100 \mu \mathrm{g}$ of G-17 were prepared and stored at $-20^{\circ} \mathrm{C}$ until the day of the study. For each study, the content of the vial was further diluted in $0.9 \%$ sodium chloride solution containing 1\% human serum albumin (Scottish National Blood Transfusion Service, Law Hospital, Carluke, Scotland, UK).

Plasma gastrin levels were measured by radioimmunoassay using antiserum $\mathrm{R} 98$, which has a sensitivity of $5 \mathrm{ng} / \mathrm{l}$ and detects both sulphated and unsulphated forms of G-17 and G-34 with equal affinity. ${ }^{28}$

Before analysis for ammonium concentration, gastric juice samples were centrifuged at $3000 \mathrm{~g}$ for 10 minutes to remove mucus. The concentration of ammonium was measured in the supernatant after dilution in $0.2 \mathrm{~mol} / 1$ phosphate buffer $\mathrm{pH} 7.4$ using a previously validated enzymatic method (Sigma Chemicals) adapted for the Cobas Mira (Roche, Welwyn Garden City, UK). ${ }^{29}$ The interassay coefficient of variation ranged from $8.5 \%$ at 2.3 $\mathrm{mmol} / 1$ gastric juice ammonium to $1.9 \%$ at 4.7 $\mathrm{mmol} / \mathrm{l}$, while the detection limit was 30 $\mu \mathrm{mol} / \mathrm{l}$. Gastric juice samples were diluted with phosphate buffer prior to analysis to prevent low gastric juice $\mathrm{pH}$ interfering with the enzyme used in the assay. ${ }^{29}$

\section{STATISTICS}

Statistical analysis was performed using a two tailed Mann-Whitney U test for unpaired data and a two tailed Wilcoxon sum rank test for paired data. A p value of less than 0.05 was considered significant. The healthy volunteers were recruited by advertising in the hospital's catchment area. The study was approved by the West of Glasgow Hospitals University NHS Trust Ethics Committee and all subjects gave written, informed consent.

\section{Results}

BASAL INTRAGASTRIC $\mathrm{pH}$

Pre-omeprazole, the median basal $\mathrm{pH}$ in the $H$ pylori negative subjects was 1.6 (range 1.27.2), and that in the $H$ pylori positive subjects was $1.6(1.2-2.9)$ ( $\mathrm{p}<0.84$; fig 1$)$. During omeprazole, the median basal $\mathrm{pH}$ in the $H$ pylori negative subjects was $3.75(1.7-8.5)$, and that in the $H$ pylori positive subjects was 7.95 (2.78.3) $(\mathrm{p}<0.002$; fig 1$)$.

BASAL PLASMA GASTRIN CONCENTRATIONS

Before omeprazole, the median basal gastrin in the $H$ pylori negative subjects was $15 \mathrm{ng} / \mathrm{l}$ (range 5-90), which was not significantly different from that in the $H$ pylori positive subjects (20 (5-75) ng/l; p<0.29; fig 2). Basal plasma gastrin was significantly higher on omeprazole than pre-omeprazole in both the $H$ pylori negative subjects $(\mathrm{p}<0.001)$ and the $H$ pylori positive subjects $(\mathrm{p}<0.003)$. However, during omeprazole, the median basal plasma gastrin concentration in the $H$ pylori negative subjects (35 (5-120) ng/l), was considerably lower than that of the $H$ pylori positive subjects (95 (30-400) ng/l; p<0.006; fig 2). 


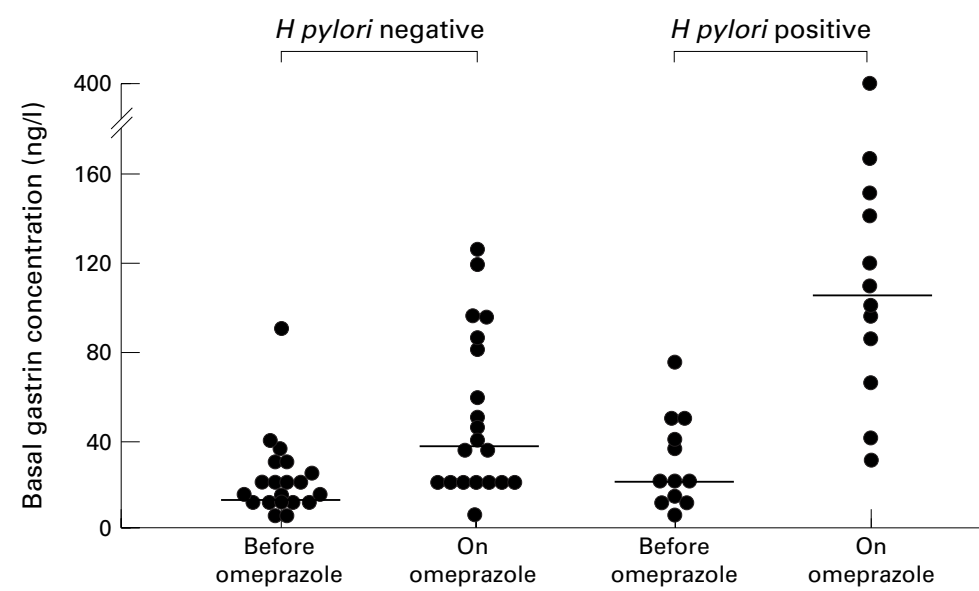

Figure 2 Basal plasma gastrin concentrations in the $H$ pylori negative and positive subjects before and during omeprazole treatment. Medians are represented by horizontal bars.

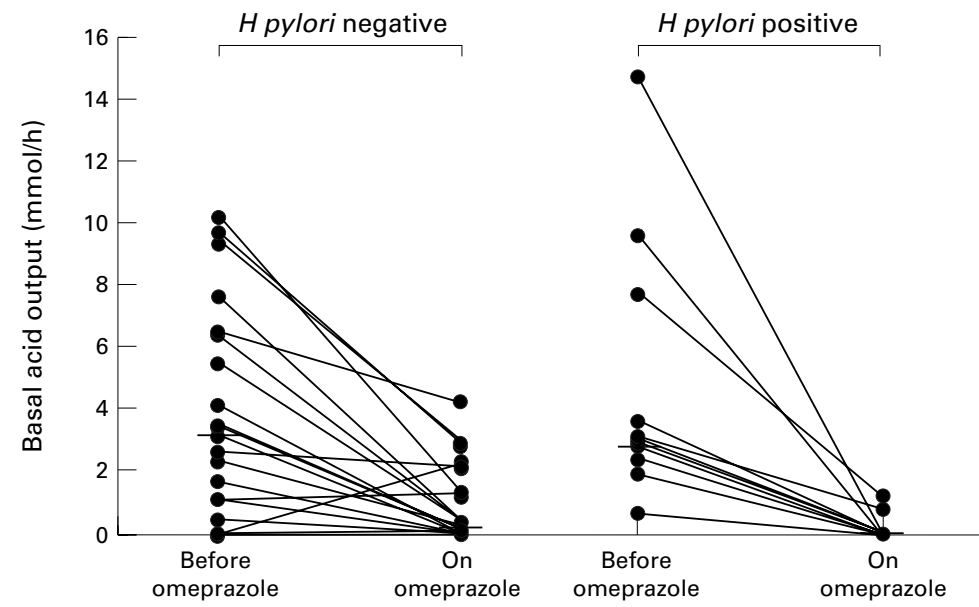

Figure 3 Basal acid output in H pylori negative and positive subjects before and during omeprazole treatment. Medians are represented by horizontal bars.

BASAL ACID OUTPUT

Before omeprazole, the median basal acid output (BAO) in the $H$ pylori negative subjects was $3.2(0.0-9.7) \mathrm{mmol} / \mathrm{h}$, which was the same as that of the $H$ pylori positive subjects (3.2 (0.714.7) $\mathrm{mmol} / \mathrm{h} ; \mathrm{p}<0.59$; fig 3). BAO was lower on omeprazole than pre-omeprazole in both $H$ pylori negative $(\mathrm{p}<0.001)$ and $H$ pylori positive subjects $(\mathrm{p}<0.003)$. However, during omeprazole, the median $\mathrm{BAO}$ in the $H$ pylori negative subjects was $0.3(0.0-4.2) \mathrm{mmol} / \mathrm{h}$, which was greater than that of the $H$ pylori positive subjects $(0.0 \quad(0.0-1.2) \quad \mathrm{mmol} / \mathrm{h} ; \mathrm{p}<0.009$; fig 3).

Before omeprazole, there was no difference in basal intragastric acidity between the two groups. However, on omeprazole, the median basal intragastric acidity of the $H$ pylori negative subjects $(7.4(0.0-36.4) \mathrm{mmol} / \mathrm{l})$, was significantly greater than that of the $H$ pylori positive subjects $(0.0 \quad(0.0-14.8) \quad \mathrm{mmol} / \mathrm{l}$; $\mathrm{p}<0.006)$.

During omeprazole, the median degree of inhibition of $\mathrm{BAO}$ in the $H$ pylori negative subjects was $93.05 \%(-18.2 \%$ to $100 \%)$, which was less than that of the $H$ pylori positive subjects $(100 \%(75 \%$ to $100 \%) ; \mathrm{p}<0.008)$. The median degree of inhibition of the basal volume of gastric juice secreted by the $H$ pylori negative subjects (43.85\%) was also less than that of the $H$ pylori positive subjects $(61.8 \%)$, although this did not reach classical statistical significance $(\mathrm{p}<0.13)$. The median degree of omeprazole induced inhibition of basal intragastric acidity of the $H$ pylori negative subjects was $83.15 \%$ which was lower than that of the $H$ pylori positive subjects $(100 \%$; $<0.007)$.

BASAL GASTRIC JUICE AMMONIUM CONCENTRATIONS AND AMMONIA OUTPUT Before omeprazole, the median basal ammonium concentration in the $H$ pylori negative subjects was $1023(396-3210) \mu \mathrm{mol} / 1$ which was lower than that of the $H$ pylori positive subjects (3285 (975-4590) $\mu \mathrm{mol} / \mathrm{l} ; \mathrm{p}<0.002)$. During omeprazole, the median basal ammonium concentration of the $H$ pylori negative subjects was $1088(387-3465) \mu \mathrm{mol} / 1$, which was also lower than that of the $H$ pylori positive subjects (2220 (360-4035) $\mu \mathrm{mol} / 1 ; \mathrm{p}<0.003)$. This represents a difference in medians on omeprazole of $1.1 \mathrm{mmol} / 1$.

From data for basal gastric juice volume and basal gastric juice ammonium concentration, the basal gastric juice ammonia output can be calculated, in a similar fashion to the calculation of gastric acid output, from the product of gastric juice volume and hydrogen ion concentration. Before omeprazole, the median basal ammonia output of the $H$ pylori negative subjects $(0.08(0.01-0.59) \mathrm{mmol} / \mathrm{h})$, was significantly lower than that of the $H$ pylori positive subjects $(0.28(0.04-0.56) \mathrm{mmol} / \mathrm{h}$; $\mathrm{p}<0.03)$. During omeprazole, the median basal ammonia output of the $H$ pylori negative subjects $(0.07(0.01-0.36) \mathrm{mmol} / \mathrm{h})$, was not significantly different from that of the $H$ pylori positive subjects $(0.13(0.02-0.31) \mathrm{mmol} / \mathrm{h}$; $\mathrm{p}<0.15)$.

\section{MAXIMAL ACID OUTPUT}

Before omeprazole, the median maximal acid output (MAO) of the $H$ pylori negative subjects was $32.4(17.9-53.0) \mathrm{mmol} / \mathrm{h}$, which was similar to that of the $H$ pylori positive subjects $(32.2$ (14.5-60.3) $\mathrm{mmol} / \mathrm{h} ; \mathrm{p}<0.50$; fig 4). During omeprazole, the median MAO of the $H$ pylori negative subjects was $18.6(3.2-39.0) \mathrm{mmol} / \mathrm{h}$, which was greater than that of the $H$ pylori positive subjects (6.0 (0.2-31.7) $\mathrm{mmol} / \mathrm{h}$; $\mathrm{p}<0.009$; fig 4). MAO was lower on omeprazole than pre-omeprazole in both the $H$ pylori negative $(\mathrm{p}<0.0009)$ and positive subjects $(\mathrm{p}<0.003)$.

Before omeprazole, there was no significant difference in intragastric acidity under maximal G-17 stimulation between the two groups. However, on omeprazole, the median intragastric acidity of the $H$ pylori negative subjects (96.0 (39.2-119.6) $\mathrm{mmol} / \mathrm{l})$, was significantly greater than that of the $H$ pylori positive subjects $(43.2(4.8-103.6) \mathrm{mmol} / 1 ; \mathrm{p}<0.0008)$.

The median degree of omeprazole induced inhibition of MAO in the $H$ pylori negative subjects $(54.6 \%(-25.2 \%$ to $89.0 \%))$ was less than that of the $H$ pylori positive subjects $(79.8 \%(27.3 \%$ to $99.4 \%) ; \mathrm{p}<0.003)$. The median degree of omeprazole induced inhibition of the volume of gastric juice secreted in 


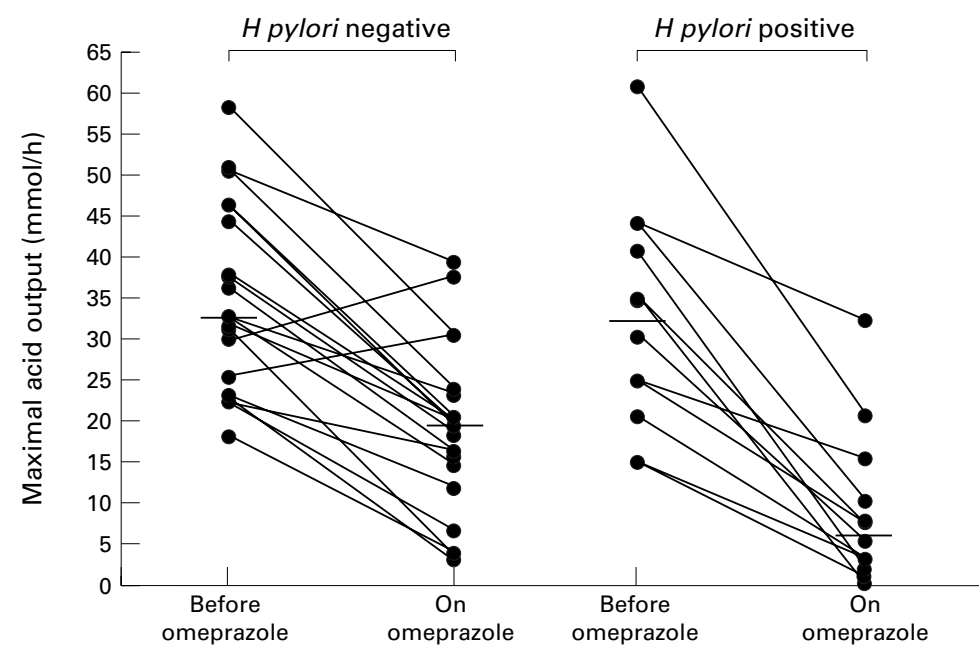

Figure 4 Maximal acid output in the H pylori negative and positive subjects before and during omeprazole treatment. Medians are represented by horizontal bars.

the $H$ pylori negative subjects $(33.0 \%(-82.6 \%$ to $81.8 \%)$ ) was less than that of the $H$ pylori positive subjects $(50.0 \%$ (1.3\% to $84.4 \%)$; $\mathrm{p}<0.04)$. The median degree of omeprazole induced inhibition of intragastric acidity of the $H$ pylori negative subjects $(29.8 \%(-16.6 \%$ to $59.5 \%)$ ) was less than that of the $H$ pylori positive subjects $(61.7 \%(26.3 \%$ to $96.1 \%))$; $(\mathrm{p}<0.001)$.

GASTRIC JUICE AMMONIUM CONCENTRATION AND AMMONIA OUTPUT DURING MAXIMAL G-17 STIMULATION

Before omeprazole, the median ammonium concentration in the $H$ pylori negative subjects was 661.5 (276-1425) $\mu \mathrm{mol} / 1$, which was lower than that in the $H$ pylori positive subjects (1958 $(178-5670) \mu \mathrm{mol} / \mathrm{l} ; \mathrm{p}<0.009)$. During omeprazole, the median ammonium concentration in the $H$ pylori negative subjects was 825 (3781485) $\mu \mathrm{mol} / 1$, which was also lower than that in the $H$ pylori positive subjects (2025 (9158055) $\mu \mathrm{mol} / 1 ; \mathrm{p}<0.0002)$. This represents a difference in medians on omeprazole of only $1.2 \mathrm{mmol} / 1$.

Before omeprazole, the median ammonia output of the $H$ pylori negative subjects $(0.16$ $(0.07-0.53) \mathrm{mmol} / \mathrm{h}$ ), was significantly lower than that of the $H$ pylori positive subjects $(0.51$ $(0.04-1.34) \mathrm{mmol} / \mathrm{h} ; \mathrm{p}<0.04)$. During omeprazole, the median ammonia output of the $H$ pylori negative subjects $(0.16 \quad(0.07-0.48)$ $\mathrm{mmol} / \mathrm{h}$ ) was not significantly different from that of the $H$ pylori positive subjects $(0.23$ $(0.10-1.07) \mathrm{mmol} / \mathrm{h} ; \mathrm{p}<0.16)$.

SUBMAXIMAL ACID OUTPUTS DURING G-17 STIMULATION

Table 1 shows median acid outputs at infusion rates of $7,20,60$, and $180 \mathrm{pmol} / \mathrm{k} / \mathrm{h}$ of G-17. Before omeprazole there were no significant differences at any G-17 infusion rate. However, on omeprazole, the acid outputs of the H pylori negative subjects were significantly greater at all infusion rates (fig 5).

Table 2 shows the median intragastric acidities in both groups, at each of the submaximal doses of G-17. The $H$ pylori negative subjects had a significantly lower median degree of omeprazole induced inhibition of acid secretion than the $H$ pylori positive subjects at each

Table 1 Acid output at submaximal doses of gastrin 17 in H pylori negative and positive subjects before and during omeprazole

\begin{tabular}{|c|c|c|c|c|}
\hline & \multicolumn{4}{|c|}{ Gastrin 17 infusion rate (pmol/kg/h) } \\
\hline & 7 & 20 & 60 & 180 \\
\hline \multicolumn{4}{|l|}{ H pylori negative, before } & $33.6(15.8-52.3)$ \\
\hline $\begin{array}{l}\text { H pylori positive, before } \\
\text { omeprazole }\end{array}$ & $7.6(0.8-25.2)$ & $16.2(2.1-33.0)$ & $23.2(6.7-51.9)$ & $27.9(10.9-60.3)$ \\
\hline H pylori negative, during & & & & \\
\hline omeprazole & $0.3(0.0-6.0)$ & $1.9(0.0-16.8)$ & $7.4(0.1-25.7)$ & $14.2(1.6-28.8)$ \\
\hline $\begin{array}{l}\text { H pylori positive, during } \\
\text { omeprazole }\end{array}$ & $0.0(0.0-4.0)^{\star}$ & $0.0(0.0-7.5) \dagger$ & $1.6(0.0-15.4) \dagger$ & $3.6(0.0-25.4) \ddagger$ \\
\hline
\end{tabular}

Acid output expressed as median (range) in $\mathrm{mmol} / \mathrm{h}$.

Acid output less in $H$ pylori positive than in $H$ pylori negative subjects at ${ }^{\star} \mathrm{p}<0.04,+\mathrm{p}<0.03, \neq \mathrm{p}<0.01$.
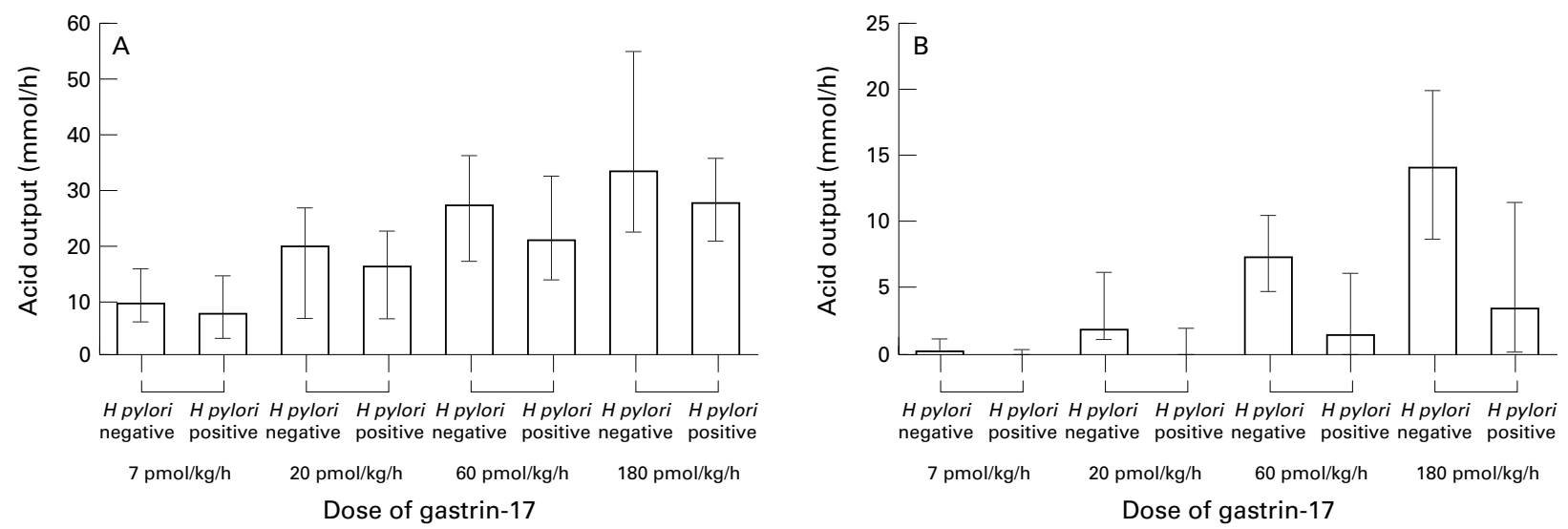

Figure 5 Median acid outputs (and ranges) to the submaximal doses of $G-17$ in $H$ pylori negative and positive subjects ( $A$ ) before and (B) during omeprazole treatment. 
Table 2 Intragastric acidity at submaximal doses of gastrin 17 in H pylori negative and positive subjects before and during omeprazole

\begin{tabular}{|c|c|c|c|c|}
\hline & \multicolumn{4}{|c|}{ Gastrin 17 infusion rate (pmol/ $/ \mathrm{kg} / \mathrm{h}$ ) } \\
\hline & 7 & 20 & 60 & 180 \\
\hline $\begin{array}{l}\text { H pylori negative, } \\
\text { before omeprazole }\end{array}$ & $\begin{array}{l}69.7 \\
(25.9-116.0)\end{array}$ & $\begin{array}{l}96.7 \\
(46.8-127.8)\end{array}$ & $\begin{array}{l}116.7 \\
(57.6-131.6)\end{array}$ & $\begin{array}{l}127.0 \\
(80.9-146.0)\end{array}$ \\
\hline $\begin{array}{l}\text { H pylori positive, } \\
\text { before omeprazole }\end{array}$ & $71.6(11-71)$ & $\begin{array}{l}93.4 \\
(18.4-114.9)\end{array}$ & $\begin{array}{l}102.4 \\
(45.6-137.4)\end{array}$ & $\begin{array}{l}117.5 \\
(58.1-137.0)\end{array}$ \\
\hline $\begin{array}{l}\text { H pylori negative, } \\
\text { during omeprazole }\end{array}$ & $7.6(0.0-57.2)$ & $29.0(0.0-96.4)$ & $66.2(8.0-108.1)$ & $\begin{array}{l}87.2 \\
(25.7-108.4)\end{array}$ \\
\hline $\begin{array}{l}\text { H pylori positive, } \\
\text { during omeprazole }\end{array}$ & $0.0(0.0-28.2)^{\star}$ & $2.4(0.0-48.0) \dagger$ & $17.4(0.0-81.1) \ddagger$ & $30.6(0.0-96.4) \S$ \\
\hline
\end{tabular}

Intragastric acidity expressed as median (range) in $\mathrm{mmol} / 1$

Acidity less in $H$ pylori positive than in $H$ pylori negative subjects at ${ }^{\star} \mathrm{p}<0.02,+\mathrm{p}<0.01, \neq \mathrm{p}<0.003$, \$p $<0.001$.

Table 3 Serum gastrin concentrations during infusions of gastrin 17 in H pylori negative and positive subjects before and during omeprazole

\begin{tabular}{|c|c|c|c|c|}
\hline & \multicolumn{4}{|c|}{ Gastrin 17 infusion rate (pmol/kg/h) } \\
\hline & 7 & 20 & 60 & 180 \\
\hline \multicolumn{2}{|l|}{ H pylori negative, } & 70.0 & 205.0 & 640.0 \\
\hline $\begin{array}{l}H \text { pylori positive, before } \\
\text { omeprazole }\end{array}$ & 37.5 & 95.0 & 242.5 & 680.0 \\
\hline $\begin{array}{l}\text { H pylori negative, } \\
\text { during omeprazole } \\
\text { H pylori positive, }\end{array}$ & 35.0 & 80.0 & 200.0 & 540.0 \\
\hline during omeprazole & $97.5^{\star}$ & $135.0^{\star}$ & 265.0 & 580.0 \\
\hline
\end{tabular}

Gastrin concentration expressed in $\mathrm{ng} / \mathrm{l}$.

*Significantly greater than $H$ pylori negative subjects during omeprazole, $\mathrm{p}<0.01$.

of the submaximal doses of G-17: $96.45 \%$ versus $100 \%$ at $7 \mathrm{pmol} / \mathrm{kg} / \mathrm{h}(\mathrm{p}<0.05) ; 88.6 \%$ versus $99.5 \%$ at $20 \mathrm{pmol} / \mathrm{kg} / \mathrm{h}(\mathrm{p}<0.02) ; 74.05 \%$ versus $93.6 \%$ at $60 \mathrm{pmol} / \mathrm{kg} / \mathrm{h}(\mathrm{p}<0.009)$; and $56.15 \%$ versus $86.95 \%$ at $180 \mathrm{pmol} / \mathrm{kg} / \mathrm{h}$ $(\mathrm{p}<0.01)$.

Before omeprazole, there were trends to a significantly higher plasma gastrin in the $H$ pylori positive subjects at the submaximal G-17 doses of 7 and $20 \mathrm{pmol} / \mathrm{kg} / \mathrm{h}$ and no significant differences at 60 and $180 \mathrm{pmol} / \mathrm{kg} / \mathrm{h}$ (table 3). However, during omeprazole, the $H$ pylori positive subjects had a significantly higher plasma gastrin at 7 and $20 \mathrm{pmol} / \mathrm{kg} / \mathrm{h}$, a trend to a difference at $60 \mathrm{pmol} / \mathrm{kg} / \mathrm{h}$, but no significant difference at $180 \mathrm{pmol} / \mathrm{kg} / \mathrm{h}$ (table 3). Due to the higher gastrin concentrations in the $H$

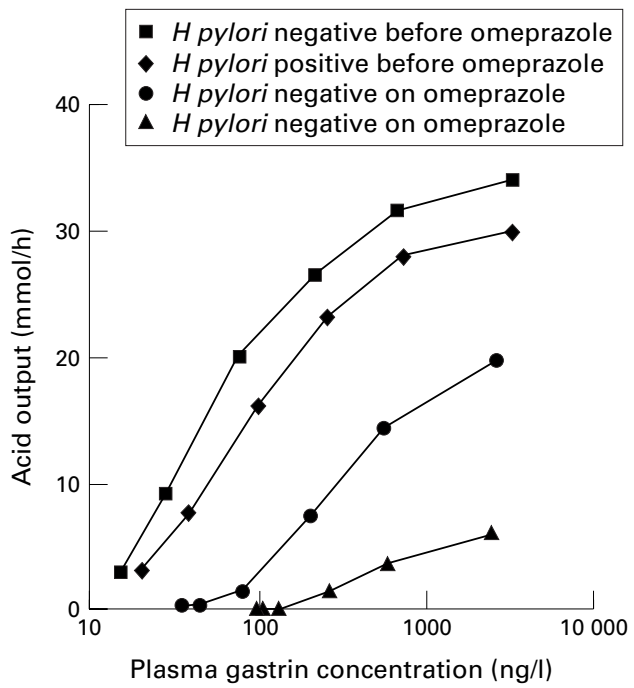

Figure 6 Median plasma gastrin concentration versus median acid output curves for the $H$ pylori negative and positive subjects before and during omeprazole treatment. pylori positive subjects during the lower G-17 infusion doses, the acid response was plotted against gastrin concentration (fig 6). This showed that on omeprazole, the $H$ pylori positive subjects had a notably reduced acid response across the full range of gastrin concentrations when compared with the $H$ pylori negative subjects.

\section{Discussion}

Previous studies have shown that during omeprazole treatment, intragastric $\mathrm{pH}$ is more notably elevated in $H$ pylori positive versus negative healthy subjects. ${ }^{21}$ In addition, intragastric $\mathrm{pH}$ on omeprazole is higher in $H$ pylori infected subjects than in the same subjects after the infection has been eradicated. ${ }^{22}{ }^{23}$ In these studies, the mean 24 hour $\mathrm{pH}$ in $H$ pylori infected subjects on omeprazole was 5.0-5.5, compared with 3.0-3.5 in $H$ pylori negative or eradicated subjects. ${ }^{21-23}$ This difference in $\mathrm{pH}$ represents a very small difference in hydrogen ion concentration of less than $1 \mathrm{mmol} / \mathrm{l}$. This has led the groups which have documented the $\mathrm{pH}$ phenomenon to conclude that it may represent nothing more than neutralisation of intragastric acid by $H$ pylori produced ammonia. ${ }^{22}{ }^{23}$ Our current studies investigated whether $H$ pylori status might be affecting the degree of suppression of gastric acid secretion produced by omeprazole, which would make the phenomenon of greater clinical significance.

Our study confirms these previous $\mathrm{pH}$ observations. The median fasting $\mathrm{pH}$ in the $H$ pylori negative subjects on omeprazole was 3.75 versus 7.95 in the $H$ pylori positive subjects. Only $25.0 \%$ of the $H$ pylori negative subjects had neutral basal $\mathrm{pH}$ values 24 hours after the previous dose of the PPI, compared with $83.3 \%$ of the infected subjects. The previous studies reporting the influence of $H$ pylori status on the $\mathrm{pH}$ raising efficacy of omeprazole had been conducted after seven days of dosing. ${ }^{21-23}$ Our present study was performed after at least six weeks of omeprazole and indicates that the phenomenon persists with longer courses of therapy.

In addition to measuring fasting intragastric $\mathrm{pH}$, we performed detailed studies of basal, submaximal, and maximal acid output. Prior to commencing omeprazole, there were no differences between the $H$ pylori positive and $H$ pylori negative healthy subjects with respect to basal and G-17 stimulated maximal acid output. This is consistent with our previous studies showing that increased acid secretion induced by $H$ pylor infection is mainly confined to duodenal ulcer patients. ${ }^{30}$ Submaximal G-17 stimulated acid output was slightly lower in the $H$ pylori positive than in the $H$ pylori negative subjects. This was more apparent when the acid output was assessed against the gastrin concentration than against the G-17 dose, as the latter does not take into account the higher endogenous gastrin level in the $H$ pylori positive subjects. The reduced acid response to gastrin in the infected subjects is consistent with our recent report of reduced sensitivity to G-17 in $H$ pylori infected healthy volunteers. ${ }^{30}$ 
Marked differences in acid secretion were apparent between the $H$ pylori positive and negative subjects on omeprazole. The median $\mathrm{BAO}$ in the $H$ pylori positive subjects was 0.0 $\mathrm{mmol} / \mathrm{h}$, compared with $0.3 \mathrm{mmol} / \mathrm{h}$ in the uninfected subjects. This difference in BAO could not be explained by any neutralising effect of ammonia produced by $H$ pylori. The median ammonia output on omeprazole was $0.13 \mathrm{mmol} / \mathrm{h}$ in the $H$ pylori positive and 0.07 $\mathrm{mmol} / \mathrm{h}$ in the $H$ pylori negative subjects. This represents a difference in ammonia output of only $0.06 \mathrm{mmol} / \mathrm{h}$, which is fivefold less than the difference in BAO. Furthermore, the greater degree of inhibition of BAO in the $H$ pylori positive versus negative subjects on omeprazole was due to a greater degree of inhibition of both volume of gastric juice secreted and its acidity. This provides further evidence that the difference in acid measured was due to greater inhibition of acid secretion in the $H$ pylori positive subjects and not merely neutralisation by either ammonia or other neutralising factors.

MAO to G-17 was also considerably lower in the $H$ pylori positive versus negative subjects on omeprazole, being $6.0 \mathrm{mmol} / \mathrm{h}$ and 18.6 $\mathrm{mmol} / \mathrm{h}$ respectively. As with $\mathrm{BAO}$, this difference in MAO of $12.6 \mathrm{mmol} / \mathrm{h}$ could not be explained by a neutralising effect of ammonia produced by $H$ pylori. The median ammonia output during maximal G-17 stimulation of omeprazole was $0.23 \mathrm{mmol} / \mathrm{h}$ in the $H$ pylori positive subjects and $0.16 \mathrm{mmol} / \mathrm{h}$ in the uninfected subjects. This difference of $0.07 \mathrm{mmol} / \mathrm{h}$ between the infected and uninfected subjects could not explain the more than 180-fold greater $12.6 \mathrm{mmol} / \mathrm{h}$ difference in median MAO. Furthermore, this difference in acid output on omeprazole was also due to a greater degree of inhibition of volume, as well as acidity, and this again excludes neutralisation by ammonia, or indeed other neutralising substances, as a feasible explanation of this observation.

Acid output on omeprazole in response to submaximal stimulation with G-17 showed a very notable difference between the $H$ pylori positive and negative subjects (figs 5 and 6 ). At a dose of $60 \mathrm{pmol} / \mathrm{kg} / \mathrm{h}$, the median acid output in the $H$ pylori negative subjects was 7.4 $\mathrm{mmol} / \mathrm{h}$ compared with $1.6 \mathrm{mmol} / \mathrm{h}$ in the $H$ pylori positive subjects. At a dose of $180 \mathrm{pmol} /$ $\mathrm{kg} / \mathrm{h}$, the corresponding values were 14.2 and $3.6 \mathrm{mmol} / \mathrm{h}$ respectively. Significant differences in acid output were also apparent at 7 and 20 $\mathrm{pmol} / \mathrm{kg} / \mathrm{h}$. Furthermore, at 7 and $20 \mathrm{pmol} /$ $\mathrm{kg} / \mathrm{h}$ of $\mathrm{G}-17$ during omeprazole, the plasma gastrin concentrations achieved during the gastrin infusion were significantly higher in the $H$ pylori positive versus the $H$ pylori negative subjects, to some degree masking the true magnitude of the difference of the acid response to gastrin at these doses of G-17. This difference in gastrin concentrations between the $H$ pylori negative and positive subjects during the lower doses of the G-17 infusion can be explained by the contribution of the higher endogenous gastrin levels in the infected subjects.
Our studies have thus shown that omeprazole produces more notable suppression of BAO, submaximal acid output, and MAO in $H$ pylori positive than in $H$ pylori negative subjects. The degree of inhibition of BAO was $100 \%$ in the $H$ pylori positive versus $93.35 \%$ in the negative subjects, $93.6 \%$ versus $74.05 \%$ for submaximal $(60 \mathrm{pmol} / \mathrm{kg} / \mathrm{h})$ acid output, and $79.8 \%$ versus $54.6 \%$ respectively for MAO.

Sensitivity to gastrin stimulation can be assessed by plotting plasma gastrin concentration against acid output at the various doses of G-17 and calculating the concentration of G-17 to produce half maximal response. ${ }^{30}$ However, in this present study, the degree of acid suppression, particularly in the $H$ pylori positive subjects on omeprazole, made it impossible to produce a concentration/acid response curve of sufficient accuracy to calculate the sensitivity to gastrin. Despite this, the observation that the gastrin concentration/acid response curve in the $H$ pylori positive subjects on omeprazole is shifted notably to the right, compared with that of the $H$ pylori negative subjects on omeprazole, is consistent with the former having a lower sensitivity to gastrin on omeprazole.

All of the previously published studies of the influence of $H$ pylori status on the response to omeprazole only measured intragastric $\mathrm{pH}$. These studies concluded that the difference in $\mathrm{pH}$ could be largely explained by neutralisation of intragastric acid by $H$ pylori produced ammonia. Our current study indicates that there is a notable difference in the degree of suppression of gastric acid secretion in $\mathrm{H}$ pylori positive versus negative subjects and that neutralisation by ammonia production cannot explain more than $20 \%$ of the difference in BAO or $0.6 \%$ of the difference in MAO. Similarly, the fact that the volume of gastric juice secreted is affected, as well as its acidity, indicates that the presence of any other neutralising substances, such as enhanced mucosal bicarbonate production ${ }^{31}$ or $H$ pylori related duodenogastric reflux ${ }^{32}$ cannot explain the observation.

The previously reported studies were performed after seven days of therapy, whereas our present study examined subjects after six to eight weeks of treatment, being representative of a typical course in clinical practice. It is possible that intragastric ammonia levels and degree of inhibition of acid varies slightly with different duration of treatment.

Our findings thus indicate that some interaction is occurring between $H$ pylori infection and omeprazole treatment which is potentiating the antisecretory efficacy of the drug. A plausible explanation for this is the intense inflammation of the oxyntic mucosa which develops in $H$ pylori positive subjects during PPI treatment. ${ }^{18-20}$ This increased gastritis is likely to impair the function of the oxyntic mucosa and thereby supplement the pharmacological effect of the drug. Recent observations by ourselves and others ${ }^{33-35}$ that there is a negative correlation between $H$ pylori associated inflammation of the oxyntic mucosa and pentagastrin stimulated peak acid output in $H$ pylori infected 
patients is consistent with this theory. Furthermore, eradication of the organism and the accompanying resolution of oxyntic inflammation result in prompt recovery of acid secretory function. ${ }^{36} \mathrm{H}$ pylori induced inflammation results in an increased production of a variety of cytokines, including interleukin 1 (IL-1), which has been shown to a very powerful inhibitor of acid secretion. ${ }^{37-39}$ An alternative or additional explanation for the more notable inhibition of acid secretion in $H$ pylori positive subjects is that ammonia produced by the urease in $H$ pylori is able to penetrate the oxyntic mucosa during omeprazole treatment due to more being in the more lipophilic unionised form at the higher intragastric $\mathrm{pH}$. This could allow increased delivery of $\mathrm{NH}_{4}^{+}$ions close to the proton pumps, where they can act as $\mathrm{K}^{+}$ surrogates, ${ }^{40}$ and lead to uncoupling of the proton pumps. ${ }^{41}$ We believe that the more profound inhibition of acid secretion in $H$ pylori positive subjects on PPI treatment is unlikely to be due to acid inhibitory products of the bacterium, ${ }^{42-44}$ as such treatment does not increase the density of bacterial colonisation of the oxyntic mucosa. ${ }^{20}$ However, one cannot exclude such products being able to gain greater access to the acid secreting cells when acid secretion is inhibited or their being more active at less acidic $\mathrm{pH}$.

Our observation that the influence of $H$ pylori status on the $\mathrm{pH}$ elevating effect of omeprazole is due to a difference in the actual acidity and volume of the gastric secretion increases the clinical importance of the phenomenon. Gastric acid is an important element of the phylogenetically conserved non-specific immune system. ${ }^{45}{ }^{46}$ The $H$ pylori positive patients rendered profoundly hypochlorhydic by PPIs are therefore likely to be at increased risk of enteric infections, as susceptibility to such infection is known to exist in other low acid states. ${ }^{47-52}$ Certainly, increased susceptibility to enteric infection on omeprazole has been reported, ${ }^{53}$ but the $H$ pylori status of the patients was not known. Our own group has recently reported a greater number of non- $H$ pylori bacteria colonising the gastric juice of $H$ pylori positive versus negative subjects during omeprazole treatment. ${ }^{54}$ Such bacterial colonisation may also result in the intragastric synthesis of potentially carcinogenic nitrosoamines. ${ }^{55}$

The findings from our present study that the degree of inhibition of both the volume and acidity of gastric secretion by omeprazole is considerably less in the $H$ pylori negative than positive subjects makes it highly likely that its efficacy in controlling acid/peptic disease will also be less in $H$ pylori negative subjects. All the clinical studies to date which have assessed the antisecretory efficacy of PPI treatment have involved groups which have been either predominantly (ulcer patients) or partially $H$ pylori positive. ${ }^{6-856-63}$ The current literature on the antisecretory efficacy of PPI treatment may thus overestimate its efficacy in the $H$ pylori negative population. There have been recent reports of difficulty in controlling intragastric acidity in some GORD subjects with PPI treatment. $^{64}$ This may be due to reduced efficacy in $H$ pylori negative subjects. Whether increasing the dose of the PPI will achieve increased control is at present unclear and will need to be addressed in $H$ pylori negative subjects.

In summary, $H$ pylori status has a major influence on the inhibition of acid secretion produced by PPI treatment. A more profound inhibition of acid secretion is seen in $H$ pylori positive subjects and this cannot be explained by acid neutralisation, either by ammonia or any other substances. While this increased antisecretory effect will facilitate the control of $\mathrm{acid} / \mathrm{peptic}$ disease, it will also predispose to enteric infections and gastric colonisation by nitrosating bacterial species.

We gratefully acknowledge the kindness of the Scottish National Blood Transfusion Service in their provision of serum albumin We are also most grateful to Dr Andrew Kelman for his kind advice on appropriate pharmacokinetic modelling. 1 Olbe L, Haglund U, Leth R, et al. Effect of substituted benzimidazole (H149/94) on gastric

2 Fellenius E, Berglind T, Sachs G, et al. Substituted benzimidazoles inhibit gastric acid secretion by blocking $\left(\mathrm{H}^{+}+\mathrm{K}^{+}\right)$ATPase. Nature 1981;290:159-61.

3 Garner A, Fadlallah H, Parsons M E. 1976 and all that! -20 years of antisecretory therapy. Gut 1996;39:784-6.

4 Howden CW, Forrest JAH, Reid JL. Effects of single and repeated doses of omeprazole on gastric acid and pepsin secretion in man. Gut 1984;25:707-10.

5 Walt RP, Gomes M de FA, Wood EC, et al. Effect of daily oral omeprazole on 24 hour intragastric acidity. BMF 1983 ; 287:12-14.

6 Cooperative Study. Omeprazole in duodenal ulceration: acid inhibition, symptom relief, endoscopic healing and recurrence. BMF 1984;289:525-8.

7 Howden CW, Hunt RH. The relationship between suppression of acidity and gastric ulcer healing rates. Aliment Pharsion of acidity and gastric
macol Ther $1990 ; 4: 25-33$.

8 Koop H, Arnold MD. Long-term maintenance treatment of reflux esophagitis with omeprazole. Prospective study in patients with $\mathrm{H}_{2}$ blocker resistant esophagitis. Dig Dis Sci 1991;36:552-7.

9 Maton PN, Vinayek R, Frucht H, et al. Long term efficacy and safety of omeprazole in patients with Zollinger-Ellison syndrome: a prospective study. Gastroenterology 1989;97: $827-36$

10 Marshall BJ, Warren JR. Unidentified curved bacilli in the stomach of patients with gastritis and peptic ulceration. Lancet 1984; : 1311-15.

11 Graham DY. Campylobacter pylori and peptic ulcer. Gastroenterology 1989;96:615-25.

12 Armstrong D. Helicobacter pylori infection and dyspepsia. Scand $\mathcal{F}$ Gastroenterol 1996;31(suppl 215):38-47.

13 Graham D, Klein PD, Opekun AR, et al. Effect of age on frequency of active Campylobacter pylori infection diagnosed by the ${ }^{13}[\mathrm{C}]$-urea breath test in normal subjects an patients with peptic ulcer. F Infect Dis 1988;157:777-80.

14 McDonagh TA, Woodward M, Morrison C, et al. Lack of independent association of $H$. pylori and coronary heart disease [abstract]. Gut 1996;38(suppl 1):A1.

15 Bugnoli M, Bayeli PF, Rappuoli O, et al. Inhibition of Helicobacter pylori urease by omeprazole. Eur 7 Gastroenterol Hepatol 1993;5:683-5.

16 McGowan CC, Cover TL, Blaser MJ. The proton pump inhibitor omeprazole inhibits acid survival of Helicobacter pylori by a urease-independent mechanism. Gastroenterology 1994;107:738-43.

17 Danon SJ, O'Rourke JL, Moss ND, et al. The importance of local acid production in the distribution of Helicobacter felis in the mouse stomach. Gastroenterology 1995;108: felis in the

18 Logan RPH, Walker MM, Misiewicz JJ, et al. Changes in the intragastric distribution of Helicobacter pylori during treatment with omeprazole. Gut 1995;36:12-16.

19 Kuipers EJ, Uyterlinde AM, Pena AS, et al. Increase of Helicobacter pylori-associated corpus gastritis during acid suppressive therapy: implications for long-term safety. $A m \mathcal{F}$ Gastroenterol 1995;90:1401-6.

20 Eissele R, Brunner G, Simon B, et al. Gastric mucosa during drug treatment with lansoprazole: Helicobacter pylori is a risk factor for argyrophil cell hyperplasia. Gastroenterology 1997;112:707-17.

21 Verdu EF, Armstrong D, Fraser R, et al. Effect of Helicobacter pylori status on intragastric $\mathrm{pH}$ during treatment with omeprazole. Gut 1995;36:539-43.

22 Verdu EF, Armstrong D, Idstrom J-P, et al. Effect of curing Helicobacter pylori infection on intragastric pH during omeprazole treatment. Gut 1995;37:743-8. 
23 Labenz J, Tillenberg B, Peitz U, et al. Helicobacter pylori augments the $\mathrm{pH}$-raising effect of omeprazole in duodenal ulcer patients. Gastroenterology 1996;110:725-32.

24 Koop H, Kuly S, Flug M, et al. Intragastric $\mathrm{pH}$ and serum gastrin during administration of different doses of pantoprazole in healthy subjects. Eur $\mathcal{F}$ Gastroenterol Hepatol 1996;8:915-18.

25 Ferrero RL, Hazell SL, Lee A. The urease enzymes of Campylobacter pylori and a related bacterium. I Clin Microbiol 1988;27:33-40.

26 Mowat C, Murray L, Hilditch TE, et al. Comparison of Helisal rapid blood test and ${ }^{14} \mathrm{C}$ urea breath test in determining $\mathrm{H}$. pylori status and predicting ulcer disease in dyspeptic patients. Am 7 Gastroenterol 1998;93:20-5.

27 Hassan HA, Hobsley M. Positioning of subject and of nasogastric tube during a gastric secretion study. $B M \mathcal{F}$ 1970;i:458-60.

28 Mulholland G, Ardill JES, Fillmore D, et al. Helicobacter pylori-related hypergastrinaemia is due to a selective pylori-related hypergastrinaemia is due to

29 Neithercut WD, El-Nujumi AM, McColl KEL. The measurement of urea and ammonium concentrations in measurement of urea and ammonium con

30 Gillen D, El-Omar E, Wirz AA, et al. The increased acid response to gastrin which distinguishes $\mathrm{H}$. pylori-infected DU patients from healthy volunteers. Gastroenterology 1998;114:50-7

31 Fandriks L, Stage L. Simultaneous measurements of gastric motility and acid-bicarbonate secretions in the anaesthetised cat. Acta Physiol Scand 1986;128:563-73.

32 Ladas SD, Katsogridakis J, Malamou H, et al. Helicobacter pylori may induce bile reflux: link between $\mathrm{H}$. pylori and bile induced injury to gastric epithelium. Gut 1996;38:1518.

33 Yasunaga Y, Shinomura Y, Kanayama S, et al. Improved fold width and increased acid secretion after eradication of the organism in H. pylori-associated enlarged fold gastritis. Gut organism in $H$. pylor

34 Feldman M, Cryer B, McArthur CE, et al. Effects of aging and gastritis on gastric acid and pepsin secretion in and gastritis on gastric acid and pepsin secretion in humans:

35 El-Omar EM, Oien K, El-Nujumi A, et al. Helicobacter pylori infection and chronic gastric acid hyposecretion. ;113:15-24.

36 Gutierrez O, Melo M, Graham DY, et al. Improved acid secretion after treatment of $\mathrm{H}$. pylori: time course [abstract]. Gastroenterology 1997;112:A413.

37 Robert A, Olafsson AS, Lancaster C, Zhang W. Interleukin-1 is cytoprotective, antisecretory, stimulates $\mathrm{PGE}_{2}$ synthesis by the stomach and retards gastric emptying. Life Sci 1991;48:123-34.

38 Wallace JL, Cucala M, Mugridge $\mathrm{K}$, et al. Secretagoguespecific effects of interleukin-1 on gastric acid secretion. Am 7 Physiol 1991;261: G559-64.

39 Taché Y, Saperas E. Potent inhibition of gastric acid secretion and ulcer formation by centrally and peripherally administered interleukin-la. Ann NY Acad Sci 1992;664: 353-68.

40 Sachs G. Helicobacter pylori and proton pump inhibitors. Gastroenterology 1997;112:1033-5.

41 Lorentzon P, Jackson R, Wallmark B, et al. Inhibition of proton potassium ATPase by omeprazole in isolated gastric vesicles requires proton transport. Biochim Biophys Acta 1987;897:41-51.

42 Cave DR, Vargas M. Effect of a Campylobacter pylori protein on acid secretion by parietal cells. Lancet 1989;i1 $187-9$.

43 Huang LL, Cave DR, Kane AV. Purification and characterisation of an acid-inhibitory protein from Helicobacter pylori [abstract]. Gastroenterology 1995;108:A839.
44 Beil W, Birkholz C, Wagner S, et al. Interaction of Helicobacter pylori and its fatty acids with parietal cells and gastric $\mathrm{H}^{+} / \mathrm{K}^{+}$ATPase. Gut 1994;35:1176-80

45 Giannella RA, Broitmans A, Zamcheck N. Gastric acid barrier to ingested micro-organisms: studies in vivo and in vitro. Gut 1972;13:251-6.

46 Drasar BS, Shiner M, McLeod GM. Studies on the intestinal flora: 1. The bacterial flora of the gastrointestinal tract in healthy and achlorhydric persons. Gastroenterology 1969; 56:71-9.

47 Hurst AF. The clinical importance of achlorhydria. BMF 1934;ii:665-9.

48 Boyd JF. Pathology of the alimentary tract in Salmonella typhimurium food poisoning. Gut 1985;26:935-44.

49 Wickramasinghe LSP, Basu SK. Salmonellosis during treatment with ranitidine. BMF 1984;289:1272.

50 Ruddell WSJ, Losowsky MS. Severe diarrhoea due to small intestinal colonisation during cimetidine treatment. BMF 1980;281:273.

51 Waddell WR, Kunz LJ. Association of salmonella enteritis with operations on the stomach. N Engl f Med 1956;255: 555-9.

52 Axon ATR, Poole D. Salmonellosis presenting with choleralike diarrhoea. Lancet 1973;i:745-6.

53 Scott HM, Neal KR, Slack RGB, et al. Omeprazole treatment, a potent risk factor for Campylobacter gastroenteritis [abstract]. Gut 1994;35(suppl 1):S30.

54 Williams C, Gillen D, Hossack M, et al. $\mathrm{H}$. pylori infection predisposes to gastric colonisation by other bacteria during omeprazole treatment [abstract]. Gut 1998;42(suppl 1): A3.

55 Correa P. Human gastric carcinogenesis: a multistep and multifactorial process-first American Cancer Society Award Lecture on cancer epidemiology and prevention. Cancer Res 1992;52:6735-40.

56 Klinkenberg-Knol EC, Festen HPM, Jansen JBMJ, et al. Longterm treatment with omeprazole for refractory reflux esophagitis: efficacy and safety. Ann Intern Med 1994;121: $161-7$.

57 Hetzel DJ, Dent J, Reed WD, et al. Healing and relapse of severe peptic esophagitis after treatment with omeprazole. Gastroenterology 1988;95:903-12.

58 Klinkenberg-Knol EC, Jansen JBMJ, Lamers CBHW, et al. Use of omeprazole in the management of reflux esophagitis resistant to $\mathrm{H}_{2}$-receptor antagonists. Scand $\mathcal{F}$ Gastroenterol 1989;24(suppl 66):88-93.

59 Lundell L, Backman L, Ekstrom P, et al. Omeprazole or high dose ranitidine in the treatment of patients with reflux oesophagitis not responding to "standard doses" of $\mathrm{H}_{2}$ receptor antagonists. Aliment Pharm Ther 1990;4:145-55.

60 Zeitoun P, Barbier P, Cayphas JP, et al. Comparison of two dosage regimens of omeprazole $-10 \mathrm{mg}$ once daily and $20 \mathrm{mg}$ weekends - as prophylaxis against recurrence of reflux esophagitis. Hepatogastroenterology 1989;36:279-80.

61 Bell NJ, Burget D, Howden CW, et al. Appropriate acid suppression for the management of gastro-oesophageal reflux disease. Digestion 1992;51(suppl 1):59-67.

62 Sontag SJ, Hirschowitz BI, Holt S, et al. Two doses of omeprazole versus placebo in symptomatic erosive esophagitis: the US Multicenter Study. Gastroenterology 1992;102:109-

63 Vigneri S, Termini R, Leandro G, et al. A comparison of five maintenance therapies for reflux esophagitis. $N$ Engl f Med 1995;333:1106-10.

64 Leite LP, Johnston BT, Just RJ, et al. Persistent acid secretion during omeprazole therapy: a study of gastric acid profiles in patients demonstrating failure of omeprazole therapy. Am f Gastroenterol 1996;91:1527-31. 